\title{
Impact on State Succession in Respect of Treaties
}

Citation for published version (APA):

Kamminga, M. T. (2009). Impact on State Succession in Respect of Treaties. In M. T. Kamminga, \& M. Scheinin (Eds.), The Impact of Human Rights Law on General International Law (pp. 99-109). Oxford University Press. https://doi.org/10.1093/acprof:0so/9780199565221.003.0005

Document status and date:

Published: 01/01/2009

DOI:

10.1093/acprof:oso/9780199565221.003.0005

Document Version:

Publisher's PDF, also known as Version of record

Document license:

Taverne

Please check the document version of this publication:

- A submitted manuscript is the version of the article upon submission and before peer-review. There can be important differences between the submitted version and the official published version of record.

People interested in the research are advised to contact the author for the final version of the publication, or visit the DOI to the publisher's website.

- The final author version and the galley proof are versions of the publication after peer review.

- The final published version features the final layout of the paper including the volume, issue and page numbers.

Link to publication

\footnotetext{
General rights rights.

- You may freely distribute the URL identifying the publication in the public portal. please follow below link for the End User Agreement:

www.umlib.nl/taverne-license

Take down policy

If you believe that this document breaches copyright please contact us at:

repository@maastrichtuniversity.nl

providing details and we will investigate your claim.
}

Copyright and moral rights for the publications made accessible in the public portal are retained by the authors and/or other copyright owners and it is a condition of accessing publications that users recognise and abide by the legal requirements associated with these

- Users may download and print one copy of any publication from the public portal for the purpose of private study or research.

- You may not further distribute the material or use it for any profit-making activity or commercial gain

If the publication is distributed under the terms of Article $25 \mathrm{fa}$ of the Dutch Copyright Act, indicated by the "Taverne" license above, 


\title{
5 \\ Impact on State Succession in Respect of Treaties
}

\author{
Menno T. Kamminga*
}

\section{Introduction}

In accordance with the consent-based nature of traditional international law a new state is free to become or not to become a party to treaties that were binding on the predecessor state. It is true that the 1978 Vienna Convention on Succession of States in Respect of Treaties provides for the continuity of obligations in respect of all treaties that were binding on the predecessor state. ${ }^{1}$ However, the Convention's approach in this respect has attracted little support from states and does not appear to reflect customary international law. The Convention entered into force only in 1996 and so far only 21 states have become parties to it (although, interestingly, this group includes many of the recent successor states). ${ }^{2}$ Contrary to the approach taken in the Vienna Convention, most states favour a 'clean slate' approach in respect of treaty succession. ${ }^{3}$

* Professor of International Law, Maastricht University. Director, Maastricht Centre for Human Rights. This is an updated and modified version of a paper that appeared in The Status of International Treaties on Human Rights, Venice Commission, Collection Science and Technique of Democracy, No. 42, Strasbourg: Council of Europe Publishing, 2006, 31-41.

${ }^{1}$ Arts. 31-35, Vienna Convention on Succession of States in Respect of Treaties, adopted 22 August 1978, entered into force 6 November 1996, 1946 UNTS 3, reproduced at 17 ILM (1978) 1488.

2 Current parties (as of June 2008) to the Vienna Convention on Succession of States in Respect of Treaties are: Bosnia and Herzegovina, Croatia, Cyprus, Czech Republic, Dominica, Ecuador, Egypt, Estonia, Ethiopia, Iraq, Liberia, Montenegro, Morocco, Saint Vincent and the Grenadines, Serbia, Seychelles, Slovakia, Slovenia, the Former Yugoslav Republic of Macedonia, Tunisia and Ukraine.

${ }^{3}$ For example, on Austria, see H. Tichy, 'Two Recent Cases of State Succession-An Austrian Perspective' (1992) 4 Austrian Journal of Public and International Law (1992) 117, 123-124; on the Netherlands, see A. Bos, 'Statenopvolging in het bijzonder met betrekking tot verdragen' (1995) 111 Mededelingen van de Nederlandse Vereniging voor Internationaal Recht 55; on the United States, see Restatement (Third) of the Foreign Relations Law of the United States (1987), para. 210(3), Reporters' Note 4. In the same vein, I.Brownlie, Principles of Public International Law, 5th ed. (Oxford University Press, Oxford 1998) 663; A. Cassese, International Law, 2nd ed. (Oxford 
There is one generally accepted exception to the clean slate doctrine. This applies in respect of treaties establishing boundaries and other territorial regimes. According to Articles 11 and 12 of the Vienna Convention on Succession of States in Respect of Treaties, such treaties are not affected by a succession of states. Unlike the principle on the continuity of obligations under treaties generally, the principle of the continuity of treaties on territorial regimes has attracted widespread support. In the Gabcíkovo-Nagimaros case the International Court of Justice identified it as a rule of customary international law. ${ }^{4}$

The question that arises is whether human rights treaties represent a second exception to the clean slate doctrine. International practice during the past two decades provides considerable evidence to test this hypothesis. During the 1990s the Union of Soviet Socialist Republics (USSR), the Socialist Federal Republic of Yugoslavia (FRY) and the Czech and Slovak Federal Republic (CSFR) disintegrated into in a large number of separate states. Among the many legal questions raised by this disintegration process was its effect on adherence to human rights treaties. The USSR, FRY and CSFR had all been parties to the main UN human rights treaties. Were the successor states emerging from these three states automatically bound by these treaties? Or were they free to adhere or not to adhere to them?

Based on a review of the practice of states, international organizations, and human rights treaty bodies during the first half of the 1990s it will be shown in this paper that the inhabitants of a territory cannot be deprived of the rights previously granted to them under a human rights treaty as a result of the fact that another state has assumed responsibility for the territory. This continuity of obligations under human rights treaties occurs automatically, ipso jure, and therefore does not require formal notification by the successor state. However, in practice confirmations by the successor state that it considers itself bound by the human rights treaties to which its predecessor was a party tend to be welcomed by the depositories and the supervisory bodies of human rights treaties because they help to clarify any ambiguities that may exist.

Since 1993, the question of the continuity or otherwise of obligations arising out of human rights treaties has been addressed by a wide range of international authorities, including the UN Commission on Human Rights, the UN human rights treaty bodies and the International Court of Justice.

(1) In 1993, 1994 and 1995, the UN Commission on Human Rights adopted three successive resolutions, introduced by the Russian Federation and adopted without a vote, entitled 'Succession of States in respect of international human rights treaties.' In those resolutions the Commission referred to the 'special

University Press, Oxford 2005) 78; M.N. Shaw, International Law, 5th ed. (Cambridge University Press, Cambridge 2003) 875.

4 Gabčikovo-Nagymaros Project (Hungary v. Slovakia), Judgment of 25 September 1997, 1997

ICJ Reports 7, para. 123.

5 Resolutions 1993/23, 1994/16 and 1955/18. 
nature' of human rights treaties and their 'continuing applicability' to successor states. The resolutions called on successor states that had not yet done so 'to confirm to appropriate depositories that they continue to be bound by obligations under international human rights treaties'.

(2) The supervisory bodies of UN human rights treaties have adopted a series of general statements in support of automatic state succession in respect of the treaties within their purview. Most importantly, in 1994 the 5th meeting of chairpersons of human rights treaty bodies declared that:

successor States were automatically bound by obligations under international human rights instruments from the respective date of independence and that observance of the obligations should not depend on a declaration of confirmation made by the Government of the successor State. ${ }^{6}$

In the same vein, the Human Rights Committee, the supervisory body of the International Covenant on Civil and Political Rights observed in its General Comment on continuity of obligations:

once the people are accorded the protection of the rights under the Covenant, such protection devolves with territory and continues to belong them, notwithstanding change in government of the State party, including dismemberment in more than one State or State succession... The Committee is therefore firmly of the view that international law does not permit a State which has ratified or acceded to the Covenant to denounce it or withdraw from it. ${ }^{7}$

(3) In the literature, the doctrine of automatic succession in respect of human rights treaties has generally been cautiously supported. ${ }^{8}$ However, while it is generally agreed that the doctrine is desirable, questions have been raised whether there is sufficient evidence of state practice and opinio juris to make it into a rule of customary international law.

The strongest and most articulate scepticism has been voiced in an article by Akbar Rasulov.' He argued that '[t]he opinio juris currently held by the successor states strongly disfavours any automaticity of succession'. He also pointed

6 UN Doc. E/CN.4/1995/80 at 4.

7 HRCt, General Comment No. 26: Continuity of obligations, 8 September 1997.

8 M.N. Shaw, 'State Succession Revisited' (1994) 5 Finnish Ybk Intl L 34, 84 (one is on the verge of widespread international acceptance of the principle that human rights treaties continue to apply within the territory of a predecessor State irrespective of a succession). P. Pazartzis, 'State Succession to Multilateral Treaties: Recent Developments' (1998) 3 Austrian Review of International \& European Law 397, 414 (principle of obligatory succession to human rights treaties seems to be developing). B. Stern, 'Les questions de succession d'Etats dans l'affaire à l'Application de la Convention pour la prevention et la repression du crime de genocide devant la Cour internationale de Justice', in N. Ando et al. (eds.), Liber Amicorum Shigeru Oda (2002) 285, 297 ('Il s'agit d'une règle en devenir, qui est encore controversée'). F. Ruiz Ruiz, 'The Succession of States in Universal Treaties on the Protection of Human Rights and Humanitarian Law' (2003) 7 International Journal of Human Rights 42, 69 (presumption in favour of continuity of human rights treaties).

9 A. Rasulov, 'Revisiting Succession to Humanitarian Treaties: Is There a Case for Automaticity?' (2003) 14 EJIL 141-170. 
out that existing international practice is limited to East European and Central European states and that no general conclusions should therefore be drawn from it about the existence of a rule of customary international law. Finally, according to Rasulov the human rights treaty bodies have not been consistent in their attitude towards state succession. More specifically, he maintained that the doctrine of automatic succession in respect of human rights treaties is ultimately unpersuasive because:

(a) Human rights treaty bodies insist on confirmations by successor states thereby creating the impression that without such confirmations treaty obligations would not continue;

(b) Human rights treaty bodies accept that successor states often accede rather than succeed to human rights treaties thereby creating the impression that their guiding principle is not continuity of obligations but freedom of choice.

More recently, the Final Report of the International Law Association's Committee on the Law of State Succession also concluded that automatic state succession in respect of human rights treaties is not a rule of customary international law. ${ }^{10}$

Without attempting an exhaustive survey I will concentrate in this contribution on practice under the European Convention on Human Rights and the International Covenant on Civil and Political Rights because the most thorough consideration of the underlying issues has occurred within the context of these two treaties.

\section{Practice under the European Convention on Human Rights}

Even sceptics agree that practice under the European Convention on Human Rights with regard to the former Czechoslovakia provides ample support for the doctrine of automatic state succession in respect of human rights treaties. ${ }^{11}$

On 1 January 1993, the Czech and Slovak Federal Republic dissolved into two independent states: the Czech Republic and the Slovak Republic. The CSFR had been a party to the European Convention on Human Rights since 18 March 1992. According to Article 66 of the Convention, only members of the Council of Europe could become parties to the Convention. On 30 June 1993, the Council of Europe's Committee of Ministers therefore admitted the two new states as members. At the same time the Committee decided that, in accordance with their express wishes, the two states were to be regarded as succeeding to

${ }^{10}$ Final Report of the Committee on the Law of State Succession, forthcoming in Report of the 73rd Conference of the International Law Association (Rio de Janeiro 2008).

11 Rasulov, supra n. 9, at 165-167. 
the Convention retroactively, with effect from 1 January 1993, i.e. from their date of independence. ${ }^{12}$ The unorthodox procedure followed in this case apparently reflected the strong desire on the part of both the existing members of the Council of Europe and its two new members to ensure seamless continuity of obligations under the Convention. ${ }^{13}$

Subsequent official records confirm this interpretation. The chart of signatures and ratifications of the Council of Europe's Treaty Office lists the Czech Republic and Slovakia as having been parties to the Convention since 1 January 1993. A footnote mentions that the dates of signature and ratification listed are by the former Czech and Slovak Federal Republic. There is no reference to any notifications by the Czech Republic or Slovakia. In other words, the continuity of obligations in this case has indeed occurred ipso jure, without action on the part of the two successor states.

Consistent with the attitude adopted by the Committee of Ministers, the European Court of Human Rights has on numerous occasions considered individual petitions against the Czech Republic and against Slovakia for violations that occurred since 18 March 1992, i.e. the date on which ratification of the Convention and recognition of the right of individual petition by the former Czech and Slovak Federal Republic took effect. ${ }^{14}$ The standard formula employed in judgments of the Court describing the facts of such cases is: 'The period to be taken into consideration began on 18 March 1992, when the recognition by the former Czech and Slovak Federal Republic, to which Slovakia [the Czech Republic] is one of the successor States, of the right of individual petition took effect.' This 'purist' approach to state succession allowing for accountability of conduct by the predecessor state apparently has not prompted any objections by the Czech Republic or Slovakia.

It is true that practice with regard to state succession under the European Convention on Human Rights has been limited to the case of the former Czech and Slovak Federal Republic. But in view of the firm precedents that have now been set by the Committee of Ministers and the European Court of Human Rights it seems highly unlikely that on future occasions a different course of action would be followed by these two institutions.

12 Council of Europe Doc. H/INF(94) 1.

13 See, J.F. Flauss, 'Convention européenne des droits de l'homme et succession d'Etats aux traités: une curiosité, la décision du Comité des Ministres du Conseil de l'Europe en date du 30 juin 1993 concernant la République tchèque et la Slovaquie' 6 RUDH (1994) 1-5.

14 See, for example, Matter v. Slovakia (App. No. 31534/96), ECtHR, Judgment of 5 July 1992, para. 52; Nemec and others v. Slovakia (App. No. 48672/99), ECtHR, Judgment of 15 November 2001, para. 30; Gajdúšek v. Slovakia (App. No. 40058/98), ECtHR, Judgment of 18 December 2001, para. 51; Chovančík v. Slovakia (App. No. 54996/00), ECtHR, Judgment of 17 June 2001, para. 18; Beňačková v. Slovakia (App. No. 53376/99), ECtHR, Judgment of 17 June 2003, para. 20; Koně́nýv. Czech Republic (App. Nos. 47269/99, 64656/01 and 65002/01), ECtHR, Judgment of 26 October 2004, para. 4; and Škodáková v. Czech Republic (App. No. 71551/01), ECtHR, Judgment of 21 December 2004, para. 30. 


\section{Practice under the International Covenant on Civil and Political Rights}

Of the various human rights treaty bodies the Human Rights Committee, the supervisory body of the International Covenant on Civil and Political Rights, has devoted most attention to the questions of principle raised by a succession of states. By the beginning of 1993, most states belonging to the former Soviet Union and Yugoslavia had either succeeded or acceded to the Covenant. At its session in March/April 1993 the Committee addressed the states that had not yet taken such action by declaring that:

all the people within the territory of a former State party to the Covenant remained entitled to the guarantees of the Covenant, and that, in particular, Armenia, Georgia, Kazakhstan, Kyrgyzstan, Tajikistan, the former Yugoslav Republic of Macedonia, Turkmenistan and Uzbekistan were bound by the obligations of the Covenant as from the dates of their independence. ${ }^{15}$

The Committee added that reports under Article 40 of the Covenant accordingly became due one year after these dates and it requested that such reports be submitted to it. ${ }^{16}$ The Committee had earlier adopted a similar decision with regard to Bosnia-Herzegovina, Croatia, and the Federal Republic of Yugoslavia. ${ }^{17}$ The Committee therefore regarded the states in question as having succeeded automatically and treated them as such by insisting that they submit implementation reports.

The Committee's approach has been remarkably successful. By the end of the 1990s all the above-mentioned states had either formally succeeded or acceded to the Covenant with the exception of Kazakhstan (see below).

While the Committee has reluctantly accepted that a successor state may opt to accede rather than succeed to the Covenant, it insists that accession takes effect retroactively to the date when the state became independent. ${ }^{18}$ This means that it regards Armenia (acceded in 1993), Azerbaijan (acceded in 1992), Georgia (acceded in 1994), Kyrgyzstan (acceded in 1994), Tajikistan (acceded in 1999), Turkmenistan (acceded in 1997) and Uzbekistan (acceded in 1995) not as parties from the customary three months after the receipt of the instrument of accession but as having been parties since 1991 when each of them became independent.

Although these states therefore acceded to the Covenant up to eight years after their independence the Committee's attitude that these notifications take effect retroactively to their date of independence has not been challenged. ${ }^{19}$ However, the Committee has accepted that reports submitted by these successor states

15 UN Doc. A/49/40, para. $49 . \quad 16$ Ibid.

17 Ibid., para. $48 . \quad 18$ Ibid., note b.

19 R. Hanski and M. Scheinin, 'The Work of the Human Rights Committee under the International Covenant on Civil and Political Rights and its Optional Protocol' in R. Hanski and 
be labelled 'initial' reports. In other words, it has not insisted for example that reports by successor states of the Soviet Union be labelled 'fourth' reports because the USSR had submitted its 'third' report before breaking up in 1991. On the other hand, the Committee has insisted that reports by the successor states cover events since their independence and it has made a point of mentioning this in its concluding observations..$^{20}$ In the case of Azerbaijan, the Committee specifically recorded its appreciation that that country's delegation when addressing questions by members of the Committee 'did not deny accountability for events that occurred in the country after the date of independence but before the date of accession'. ${ }^{21}$ The records reveal no objections to this attitude and the states in question therefore appear to have acquiesced in it. Some states have submitted reports that specifically covered the period since independence rather than merely the period since their accession. ${ }^{22}$

The last former republic of the USSR to clarify its position was Kazakhstan. Kazakhstan became independent on 16 December 1991 but it only proceeded to sign the Covenant on 2 December 2003 and to ratify it on 24 January 2006. This would appear to suggest that Kazakhstan did not consider itself in any way bound by the Covenant. However, this did not daunt the Committee. Until its date of ratification the Committee continued to treat Kazakhstan as having remained a party to the Covenant by way of succession and it listed the country as such in its annual reports. It also continued to invite Kazakhstan to present its (initial) report. In a footnote in its annual reports the Committee pointed out:

Although a declaration of succession has not been received, the people within the territory of the State-which constituted part of a former State party to the Covenantcontinue to be entitled to the guarantees enunciated in the Covenant in accordance with the Committee's established jurisprudence. ${ }^{23}$

In contrast, in the UN document entitled 'Multilateral Treaties Deposited with the Secretary-General', prepared by the Treaty Section of the UN Office of Legal Affairs, Kazakhstan was not listed as a party to the Covenant. The documents therefore reflect a fundamental difference of approach between the UN Office of Legal Affairs, which carries out depositary functions on behalf of the SecretaryGeneral, and the Human Rights Committee, the body elected by the parties to supervise the implementation of the Covenant. While the Office of Legal Affairs has followed a passive approach consisting of recording the intentions of states,

M. Scheinin, Leading Cases of the Human Rights Committee (Institute for Human Rights, Turku/ Åbo 2003) 8 .

20 See, for example, Concluding observations on the initial report of Armenia, UN Doc. CCPR/ C/79/Add.100, Concluding observations on the initial report of Kyrgyzstan, UN Doc. CCPR/ $\mathrm{CO} / 69 / \mathrm{KGZ}$, and Concluding observations on the initial report of Uzbekistan, UN Doc. CCPR/ $\mathrm{CO} / 71 / \mathrm{UZB}$.

${ }^{21}$ Concluding observations on the initial report of Azerbaijan, UN Doc. CCPR/C/79/Add.38.

22 Initial report by Uzbekistan, UN Doc. CCPR/C/UZB/99/1.

23 E.g. UN Doc. A/59/40 (vol. I) Annex I, note d. 
the Human Rights Committee has relied on a principled philosophy that is independent from the conduct of states.

Significantly, when Kazakhstan finally ratified it did so without any reservations. In fact, none of the successor states that have acceded to the Covenant has entered any reservations. Arguably, this reflects the opinio juris that in view of the continuity of obligations which pertains, a successor state is not entitled to enter reservations that had not been made by the predecessor state.

In spite of its innovative actions, the Human Rights Committee's attitude has been less radical than that of the European Court of Human Rights. Unlike the European Court, the Committee has not always insisted on holding successor states explicitly accountable for unlawful conduct by the predecessor state. However, this may be partly due to the fact that the nature of the reporting procedure generally does not force treaty bodies to make specific determinations on a state party's obligations ratione temporis.

\section{The Attitude of the International Court of Justice}

The International Court of Justice has so far avoided taking a position one way or the other although it was offered the opportunity to do so in the Bosnian Genocide case. In response to an argument of automatic succession in respect of human rights treaties made by Bosnia-Herzegovina ${ }^{24}$ the Court observed:

Without prejudice as to whether or not the principle of 'automatic succession' applies in the case of certain types of international treaties or conventions, the Court does not consider it necessary, in order to decide on its jurisdiction in this case, to make a determination on the legal issue concerning State succession. ${ }^{25}$

In their separate opinions to this judgment only one individual judge expressed clear views on the issue of automatic succession in respect of human rights treaties. Judge Weeramantry argued that there was indeed a principle of automatic succession in regard to the Genocide Convention. Judge Higgins has expressed sympathy for the idea in an academic article. ${ }^{26}$

Based on the references in the judgment to the humanitarian nature of the Genocide Convention at least one author has suggested that the Court 'appeared to endorse, tacitly, at least, the conclusion drawn by Bosnia-Herzegovina as to automatic succession. ${ }^{27}$ In my opinion, it would be inappropriate to draw such

${ }^{24}$ Application of the Convention on the Prevention and Punishment of the Crime of Genocide (Preliminary Objections) (Bosnia-Herzegovina v. Yugoslavia), Judgment of 11 July 1996, 1996 ICJ Reports 595, para. 21.

25 Ibid., para. 23.

26 R. Higgins, 'The International Court of Justice and Human Rights', in K. Wellens (ed.), International Law: Theory and Practice. Essays in Honour of Eric Suy (Nijhoff, The Hague 1998), 691, 696-697.

27 M.C.R. Craven, 'The Genocide Case, the Law of Treaties and State Succession' (1997) 68 BYIL 127, 152. 
an inference. It should however be pointed out that in its more recent advisory opinion on The Wall the Court demonstrated a tendency to closely follow the practice of the treaty bodies when interpreting human rights treaties. ${ }^{28}$ One might therefore speculate that, if obliged to make up its mind, the Court would follow the treaty bodies' line in favour of automatic succession but this is no more than speculation.

\section{Concluding Observations}

Human rights treaty bodies have taken the view that the protection accorded by human rights treaties devolves with territory and is not affected by state succession. Successor states therefore remain bound by human rights treaties from their date of independence and this is not dependent on any confirmation made by them.

This regime represents a significant exception to the general rule of noncontinuity of treaty obligations. In effect, it puts human rights treaties in the same league as treaties establishing boundaries and other territorial regimes.

Although only two human rights treaties have been surveyed in any detail in this paper the approach taken by the supervisory bodies is broadly consistent as evidenced by the 1994 joint statement by the chairpersons of UN treaty bodies. ${ }^{29}$ While the actual practice of the supervisory bodies has not been entirely uniform, inconsistencies relate to matters of detail and not to matters of principle.

Practice under the European Convention on Human Rights has been the most principled and far reaching. Within six months of the collapse of the Czech and Slovak Federal Republic the Council of Europe's Committee of Ministers reacted by deciding that the Czech Republic and the Slovak Republic were to be regarded as having succeeded to the Convention retroactively from their date of independence. The European Court of Human Rights followed suit by holding the two new states accountable for any breaches committed by the predecessor state.

The UN human rights treaty bodies have generally been more restrained in their attitude to state succession. They have accepted that successor states accede rather than succeed to their treaties and that there may be significant delays in this process; they have accepted that successor states submit implementation reports that are labelled 'initial' even if the predecessor state had already submitted one or more reports in the past; and they have not held successor states accountable for breaches by the predecessor state. In other words, while they have firmly insisted on continuity of substantive obligations they have adopted a pragmatic approach towards achieving this result and they have not insisted on full continuity of accountability.

28 Legal Consequences of the Construction of a Wall in the Occupied Palestinian Territory, Advisory Opinion of 9 July 2004, 2004 ICJ Reports 136, paras. 109-112 and 136.

29 Supra n. 6. 
It may be argued that notifications by the successor state have a constitutive rather than confirmative character and therefore are incompatible with the automatic nature of treaty succession in respect of human rights treaties. The repeated calls upon successor states to 'confirm' their obligations under human rights treaties by political bodies such as the UN Commission on Human Rights and expert bodies such as the UN treaty bodies would support such an interpretation.

But in my view calls on states to 'confirm' their obligations do not serve such a constitutive function. For example, in 1977 the UN General Assembly called on member states to reinforce their support for the Declaration against Torture by making unilateral declarations by which they would agree to comply with the Declaration. ${ }^{30}$ Thirty-three states made such declarations. It has never been suggested that by calling on states to make such declarations the General Assembly was in fact undermining the prohibition of torture under customary international law. On the contrary, human rights lawyers widely regarded the declarations that were made as reinforcing the prohibition. ${ }^{31}$

Significantly, the three resolutions on state succession in respect of human rights treaties adopted by the UN Commission on Human Rights in which states were called upon to 'confirm' that they continue to be bound, also refer to the 'special nature' of human rights treaties and their 'continuing applicability' to successor states. Any constitutive nature of such confirmations would be difficult to reconcile with such language.

While the Human Rights Committee has reluctantly accepted that a successor state may opt to accede rather than succeed to the International Covenant on Civil and Political Rights, it insists that accession takes effect retroactively to the date when the successor state became independent.

The exceptional case of Kazakhstan, rather than serving to undermine the doctrine of automatic succession, has enabled the Human Rights Committee to demonstrate the ultimate consequence of the doctrine by treating Kazakhstan as a state party retroactively to its date of independence.

It is true that international practice relating to succession of states in respect of human rights treaties has been limited to the 20-odd Central and East European states that gained their independence as a result of the collapse of the USSR, the FRY and the CSFR in the 1990s. Practice relating to Hong Kong and Macau, while fully consistent with the doctrine of automatic succession to human rights treaties, does not have the same evidentiary value because continuity of obligations in respect of these territories is based on bilateral agreements between China and the United Kingdom and China and Portugal, respectively. In view of the widespread support from states and the lack of opposition from successor states it would however be unduly restrictive to assume European regional custom only.

30 UN General Assembly Res. 32/64, 8 December 1977.

31 See N.S. Rodley, The Treatment of Prisoners under International Law, 2nd ed. (Clarendon Press, Oxford) 42-43, 61-62. 
It is also true that the doctrine of the continuity of obligations under human rights treaties is driven primarily by the human rights treaty bodies, in particular the Human Rights Committee. Similarly, the continuity of treaties in the field of international humanitarian law is driven by the International Committee of the Red Cross and the continuity of treaties in the field of international labour law is driven primarily by the International Labour Office. It is uncertain whether successor states would have embraced the doctrine if they had been left to make up their own minds. But it is legally significant that the practice of the treaty bodies has not been objected to by states. This contrasts, for example, with the treaty bodies' practice relating to reservations, which has been strongly objected to by some states. $^{32}$

The doctrine is evidence of the special status of human rights treaties in international law. It demonstrates that obligations under human rights treaties not only enjoy a superior ranking in comparison to other international standards but that they are also permanent and inalienable. In other words, while states may come and go obligations under human rights treaties remain as they are. Charles de Gaulle's celebrated words 'Les traités, voyez vous, sont comme les jeunes filles et comme les roses, ça dure ce que ça dure' apparently are not applicable to human rights treaties.

However, the doctrine of automatic succession in respect of human rights treaties has not been endorsed — or rejected for that matter - by the International Court of Justice or the International Law Commission. In the Bosnian Genocide case, the Court passed up an opportunity to take a position on the doctrine. The Vienna Convention on Succession of States in Respect of Treaties still provides for automaticity for treaties on territorial regimes but not for human rights treaties. There are no current initiatives to amend the Convention in order to change this situation. It must therefore be concluded that the doctrine of automatic succession in respect of human rights treaties has so far remained lex specialis. There is no strong evidence that it has become part of general international law.

32 Compare the objections to Human Rights Committee General Comment No. 24 by the United States, and the United Kingdom (1995 Annual Report of the Human Rights Committee, UN Doc. A/50/40 vol. I, 126-134) and France (1996 Annual Report of the Human Rights Committee, UN Doc. A/51/40 vol. I, 104-106). 
